Liberal Trade and Japan

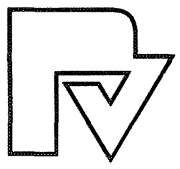




\section{Contributions to Economics}

Albrecht Ritschl

Prices and Production

- Elements of a System - Theoretic

Perspective -

1989. 159pp. Softcover DM 59,-

ISBN 3-7908-0429-0

Arnulf Grübler

The Rise and Fall of Infrastructures

- Dynamics of Evolution and

Technological Change in Transport -

1990. 305pp. Softcover DM 85,-

ISBN 3-7908-0479-7

Peter R. Haiss

Cultural Influences on Strategic Planning

1990. 188pp. Softcover DM 65,-

ISBN 3-7908-0481-9

Manfred Kremer/Marion Weber (Eds.)

Transforming Economic Systems:

The Case of Poland

1992. 179pp. Softcover DM 69,-

ISBN 3-7908-91415-3 


\section{Marcel F. van Marion}

Liberal Trade

and Japan

The Incompatibility Issue

With 31 Figures

Physica-Verlag

A Springer-Verlag Company 


\section{Series Editors}

Werner A. Müller

Peter Schuster

\section{Editor}

Dr. Drs. Marcel F. van Marion

Johan de Wittlaan 5

NL-5631 AP Eindhoven / The Netherlands

ISBN-13: 978-3-7908-0699-1 e-ISBN-13: 978-3-642-46942-8

DOI: $10.1007 / 978-3-642-46942-8$

CIP-Titelaufnahme der Deutschen Bibliothek

Marion, Marcel F. van:

Liberal trade and Japan : the incompatibility issue / Marcel F.

van Marion. - Heidelberg : Physica-Verl., 1993

(Contributions to economics)

ISBN-13: 978-3-7908-0699-1

This work is subject to copyright. All rights are reserved, whether the whole or part of the material is concerned, specifically the rights of translation, reprinting, reuse of illustration, recitation, broadcasting, reproduction on microfilms or in other ways, and storage in data banks. Duplication of this publication or parts thereof is only permitted under the provisions of the German Copyright Law of September 9, 1965, in its version of June 24, 1985, and a copyright fee must always be paid. Violations fall under the prosecution act of the German Copyright Law.

(C) Physica-Verlag Heidelberg 1993

Softcover reprint of the hardcover 1st edition 1993

The use of registered names, trademarks, etc. in this publication does not imply, even in the absence of a specific statement, that such names are exempt from the relevant protective laws and regulations and therefore free for general use.

7100/7130-543210 - Printed on acid-free paper 


\section{ACKNOWLEDGEMENTS}

The writing of this book may well not even have been attempted without Frits Bolkestein, whose intellectually persuasive force stimulated an exciting period of great personal and professional significance. I hope that the result has not disappointed him.

That the book has been completed is primarily attributable to professors Henk de Haan and Catrinus Jepma. They have not only been extremely encouraging and inspirational, but have also given their admirable capacity to create enthusiasm for economics, in general, and for practically applicable theoretical tools, in particular, through which they significantly contributed to the satisfaction of working on the subject. They appear to be naturally gifted as economists and stimulating persons.

That it has been written in a shorter period than was originally planned is due to Ton Weegels. He not only installed the computer in the attic and taught me how to use it, he also had a steadying influence when texts seemed to have perished forever, reviving than with innumerable interventions. He has demonstrated natural gifts in economics when, as usually good natured, drawing diagrams in lunch hours, his quick mind preventing starvation.

Many data on trade in electronics have been made available by Henry Anus, that invaluable companion in arms, whom I have known since we founded the European Association of Consumer Electronics Manufacturers. Working with him and such other outstanding persons from the electronics industry as Claude Bonnet, Jean Caillot, Keld Harder, Karl-Heinz Kotter, Hermann Moessner, Dicky Norman, and Riccardo Viziale - to mention just a few - has been an extraordinary experience.

Two people have had a decisive influence on the career that allowed the gaining of practical knowledge and experience in the subjects described. The first is Coen Ramaer, who offered a job and plenty of scope of action and an example of an inquisitive mind. The other is Henk Bodt, who demonstrated that a combination of motivation, trust, sensible discipline and businesslike accountability can give people satisfaction in their work and, I hope, increase their efficiency. He taught that even in external relations, planning is indispensable, because it fixes responsibilities and establishes weak spots.

The English of this book would have remained unintelligible in parts, had not Stephen Atkinson elaborated on it, so that I sometimes hardly recognised my own writing. Also it would have remained illegible had not Diny Molemans intelligently and diligently sacrificed so many a lunch hour, creating order where chaos existed and meticulously processing the text into what may be hoped to be a reasonably wellordered whole. 
The tolerance of colleagues should be mentioned. Their positive and very cooperative spirit was a great asset. It is impossible to mention all those competent people in the Commission of the European Communities and the member states, who have contributed so expertly to effectively liberal trade.

My wife's love, patience and understanding as well as agreement with the allocation of resources and scarce leisure time to the project, ensured that the papers on which this book is based were not thrown away prematurely and that enjoyable economic literature has been procured. If she had not stimulated me to persevere, I would have missed this exceptional experience.

Eindhoven, March, 1993. 


\section{CONTENTS}

LIST OF TABLES

IX

LIST OF DIAGRAMS

LIST OF GRAPHS

INTRODUCTION

PART A. LIBERAL ECONOMY: CONCEPTION, CONCEPTS AND CONFLICTS

$\begin{array}{ll}\text { I. Ideology and the Multilateral Trade System } & 7\end{array}$

II. Trade Theory and Ideology: Some Basic Issues $\quad 19$

III. Japan, as a Trade Issue $\quad$ " $\quad 35$

PART B. JAPAN AND TRADE: CARTELS, COHERENCE AND COMPETITION

IV. Power and Trade: The Family Economy $\quad 55$

$\begin{array}{ll}\text { V. Harmony or Economic Power: Japan's Trade Cohesion } & 77\end{array}$

$\begin{array}{ll}\text { VI. Cementing the Structure: People, Power and Policies } & 109\end{array}$

VII. Economics of the Japanese System and the International Trade Model

$\begin{array}{ll}\text { X. Own Brand Laser Beaming: Compact Disc Players } & 207\end{array}$

XI. Big Battle, Micro-Electronics 
VIII

PART D. JAPAN'S SYSTEMATIC DUMPING: AN APPROACH TO THE PROBLEM

XII. An Isolated Cartel Economy in World Trade

XIII. Epilogue

REFERENCES 


\section{LIST OF TABLES}

I.1. Average tariff levels 1913 and 1925

III.1. Ratio of manufactured imports to GNP 36

III.2. Korean exports (1990) according to destination 36

III.3. Average and minimum Korean VCR prices compared with Japanese 39

IV.1. Electronics companies in gurupu $\quad 63$

IV.2. Share holders in Honda and Yamaha 65

$\begin{array}{ll}\text { IV.3. } & \text { Cross-share holdership } \\ & 66\end{array}$

V.1. Captive retail shops, exports and domestic share in turnover 78

V.2. Market share of electrical appliances manufacturers in Japan (1989) 79

V.3. Gross margin of distribution in relation to total turnover 82

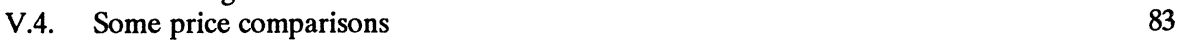

V.5. Japanese CTV sets recalled for inspection in Japan $\quad 86$

V.6. Korean export performance in Japan 95

$\begin{array}{lll}\text { V.7. Six products and and protective effect of captive } & 98 \\ \text { trade } & \end{array}$

$\begin{array}{lll}\text { V.8. Tariff quota effect of captive distribution } & 99\end{array}$

VI.1. Wage differentation according to firm size in the car and allied industries 112

$\begin{array}{ll}\text { VI.2. Product range in the West and Japan compared } & 116\end{array}$

$\begin{array}{lll}\text { VII.1. Battle of the Sexes } & 140\end{array}$

VIII.1. Original Equipment Manufacturers' and Stencil Brand CTV Supplies 162

IX.1. VHS Original Equipment Manufacturers' Supplies $\quad 186$

$\begin{array}{ll}\text { IX.2. The non-written quantitative VCR agreement } & 192\end{array}$

$\begin{array}{ll}\text { X.1. Japanese CD players market forecast } & 213\end{array}$

XI.1. Japanese producers of computers and "strategic alliances" 226

XI.2. Personal Computers and their content 227

XI.3. Ranking of Worldwide Semiconductor and Computer Sales, $1990 \quad 228$

XI.4. Relative positions of semiconductor firms 229

XI.5. Non-agricultural goods under residual Japanese import restrictions 230

XI.6. Japanese market of computer and ICs and import growth and shares 232

$\begin{array}{ll}\text { XI.7. Managed integrated circuits trade } & 241\end{array}$

XII.1. Anti-Dumping Duties for Japanese majors 256

XII.2. Prisoner's Dilemma 266

$\begin{array}{ll}\text { XII.3. Prisoner's Dilemma and free rider } & 268\end{array}$ 


\section{LIST OF DIAGRAMS}

II.1. Free choice, perfect competition 23

$\begin{array}{ll}\text { IV.1. The nine groupings } & 60\end{array}$

IV.2. The Nimomu-kai (Second Thursday Club) 61

$\begin{array}{ll}\text { IV.3. Gurupu preference and efficiency } & 70\end{array}$

V.1. Distribution in consumer electrical appliances $\quad 80$

V.2. The small and the big in Japan $\quad 92$

V.3. Learning curve and scale of production 93

VII.1. Bertrand behaviour 137

VII.2. Bertrand behaviour and keiretsu trade 139

VII.3. Cournot conduct $\quad 141$

VII.4. Keiretsu trade and export dumping 143

VII.5. Dumping and "trade reversal" 146

VII.6. Forward pricing and dumping $\quad 149$

XII.1. Profit and dumping of the great and the smaller 258 


\section{LIST OF GRAPHS}

III.1. Comparative advantage in microwave ovens? 38

III.2. Japanese and Korean VCRs in the USA and Japan 40

VIII.1. Penetration rate of CTV in Japan and market shocks in USA

VIII.2. Japanese average ex-factory production and export price and sales

VIII.3. Japanese imports into U.S. and market share, inclusive of stencil brand supplies in U.S.

VIII.4. American ex-factory prices compared with Japanese domestic and export prices

VIII.5. Continued defensive

$\begin{array}{lll}\text { IX.1. Average shipment prices in 1,000 Yen } & 187\end{array}$

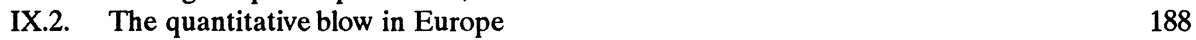

$\begin{array}{ll}\text { IX.3. Japan's presence in the EEC } & 194\end{array}$

IX.4. Japan's and Korea's VCR shipments 196

$\begin{array}{ll}\text { X.1. Price havoc in Europe } & 214\end{array}$

X.2. Fall in prices since $1984 \quad 218$

$\begin{array}{ll}\text { X.3. Circumvention by trade deflection } & 219\end{array}$

XI.1. Computer and IC trade of Japan 234

$\begin{array}{ll}\text { XI.2. Managed trade } & 239\end{array}$

XI.3. Prices and costs of 1M DRAM 242 